\title{
Effect of Different Combination of Nitrogen Sources on the Yield of Direct Seeded Rice (Oryza sativa)
}

\author{
Supreet Saajan*, Sumeet Kour, Neetu, Ishita Walia and Arun Kumar
}

Department of Agronomy, School of Agriculture, Lovely Professional University, JalandharDelhi G.T. Road (NH-1), Phagwara, Punjab, India

*Corresponding author

\section{Keywords}

Azotobacter, Bio fertilizer, Inorganic, Organic, Integrated nutrient management

Article Info

Accepted:

04 February 2018

Available Online:

10 March 2018

\section{A B S T R A C T}

Rice (Oryza sativa) is a staple food in many countries especially in the Asian part of the world. Rice $(2 n=2 x=24)$ serves as main food diet by the majority of people. It is strictly diploid in nature. The demand for rice is increasing day by day due to increase in population pressure in India. A field experiment was conducted during Kharif season in 2015 to check the effect of different nitrogen sources on the yield of Direct Seeded Rice and also to find out the best combination of nitrogen sources for integrated nutrient management. Data was recorded and analyses of data revealed that treatment $\mathrm{T} 7$ (azotobacter $+25 \%$ vermicompost $+50 \%$ RDN) gave the significant result in growth and yield attributes with respect to control treatment (inorganic sources only).

\section{Introduction}

Rice (Oryza sativa) is a major cereal crop in world. It is widely consumed by majority of human population as a staple food. Day by day demand of rice is increasing in India due to increase in the population and change in diet habit of people. More than $90 \%$ of total rice production in world is produced and consumed in Asia. India and China are the most important countries of Asia in rice production. Rice play very important role in Indian food production and consumption. It is no wrong to say that rice is life line of India. Due to increase in the population pressure is very important to increase in the agriculture production for maintain food security in India. No doubt use of chemical fertilizer lead to huge increase in the production but from many years continuously along with intensive farming it also impaired the soil fertility and productivity (Vinod Dubey et al., 2012). So, to overcome this problem integrated nutrient management is the best way. In integrated nutrient management we using all the possible ways to provide the nutrient to crops and not depend only on chemical fertilizers. Integrated nutrient management not only supplies the nutrient to crops but also maintains long term soil fertility. It also full fills the theory of 
sustainable agriculture. Continuous use of inorganic fertilizer causes the deficiency of micro nutrient and create imbalance in soil physicochemical properties of soils. On the other hand, long term use of integrated nutrient management(INM) increase in the organic carbon, macro nutrients [nitrogen $(\mathrm{N})$, phosphate $(\mathrm{P})$, potassium $(\mathrm{K})]$, and micronutrient [iron $(\mathrm{Fe})$, manganese $(\mathrm{Mn})$, zinc $(\mathrm{Zn})$, copper $(\mathrm{Cu})$, and boron (B)] availability and also improved physical properties leading to sustenance of fertility (Maji and Mondal,2004). NPK status of the soil is enhanced by addition of organic sources of the nutrient. Incorporation of organic nutrient sources in soil improves the soil properties and productivity in rice-rice growing system (Sireesha et al., 2017). Use of synthetic fertilizers has increased the productivity of crops, but also have many harmful effects to environmental like soil pollution, air pollution, water pollution, human health's related problem and also making the crop productivity unsustainable (Eid et al., 2006). However, use of the organic and inorganic nutrient sources in combination is very effective way to added nutrients which results increase in production and productivity of crops without causing any harmful effect to environment. Integrated nutrient management INM also helps in managing the biological waste by incorporation into the soil which provides the nutrients to subsequent crops. Keeping all above facts in view the study was conducted to find the best combination of the organic and inorganic nutrient sources in rice without deteriorating the productivity.

\section{Materials and Methods}

\section{Location of experimental site}

The Experiment was conducted entitled with "Effect of different combinations of Nitrogen Sources on Yield of Direct Seeded Rice" at the farm Department of Agronomy, Lovely
Professional University, Phagwara on rice (Oryza sativa) during Kharif season in year 2016-2017. The farm is situated at $31^{\circ} 22^{\prime} 31.81^{\prime}$ ' North latitude and $75^{\circ} 23^{\prime} 03.02^{\prime \prime}$ East longitude with $252 \mathrm{~m}$ average elevation above mean sea level. It is comes under sub-tropical region in central plane of state agro climatic zone. Region of experimental site comes under sub tropics with cool weather in winter season, hot weather in summers and distant rainfall period in month of July, August and September. South west monsoon is main source of rainfall in this region.

\section{Experimental detail}

A Randomized complete block design was used with nine treatment and three replications has been used in this experiment. Three biofertilizers (cyanobacteria, azotobacter and Azospirillum), two organic sources (Farm yard manure and Vermicompost) and inorganic fertilizer (urea) were used as source of nitrogen in different combinations. Detailed number of treatment is presented in Table 1.

\section{Agronomic practices}

Pusa basmati 1121 variety of rice was used in this experiment. It was released in 2008 and recommended by Punjab Agricultural University (PAU) to grow in Punjab. It is about $120 \mathrm{~cm}$ tall. It has extra-long grain with good cooking quality with average maturity time of 137 days (Anonymous, 2017). Seed was sown on 16 June in Kharif season. Ten kg seed rate per acre was used for direct seeding rice with recommended row to row spacing of $20 \mathrm{~cm}$. The seed was sown about approximately depth of $2-3 \mathrm{~cm}$. Full dose of phosphorus (P2O5) $30 \mathrm{~kg} / \mathrm{ha}$ and potassium (K2O) $30 \mathrm{~kg} / \mathrm{ha}$ along with nitrogen as per treatment was applied as basal dose. Remaining nitrogen from $125 \mathrm{~kg} / \mathrm{ha}(100 \%$ RDN) were applied as per treatments in three 
equal splits at 3, 6 and 9 weeks after sowing. Data collection

Crop growth parameters (Plant height and number of tillers) and yield parameters (Number of panicle per hill, Grain per panicle, Grain Yield per plot) were observed. Crop growth parameters (Plant height, number of tillers and number of leaves) were measured at 30 DAS, 45 DAS, 60 DAS, 75 DAS and Yield parameters were measured at time of crop harvesting.

\section{Statistical analysis}

Data were analyzed by Duncan's Multiple Range Tests (DMRT) for separation of means with a probability $\mathrm{p}<0.05$. Difference between mean values was evaluated by Analysis of Variance (ANOVA) using the software SPSS 16.

\section{Results and Discussion}

\section{Plant height}

Data found from this experiment at different growth stages treatment number T7 (50\% RND $+25 \%$ vermicompost $+25 \%$ azotobacter) showed significant superior result over the control treatment at all different growth stages(Table 2). Densilin et al., (2011) found similar results in experiment with combine use of vermicompost and bio-fertilizer found significant increase in the growth and yield parameters because bio-fertilizer change the microbial status of the soil which improve the nutrient status and increase soil fertility.

\section{Number of tillers}

Data recorded at from this experiment found that treatment $\mathrm{T} 7$ (azotobacter $+25 \%$ vermicompost $+50 \% \mathrm{RDN})$ and $\mathrm{T} 9$ (Azospirillum $+25 \% \quad$ vermicompost + $50 \% \mathrm{RDN})$ gave significant higher number of tillers in comparison to control treatment on the basis of statistical analysis (Table 3). Treatment number T7 shows maximum 24.20 number of tillers per hill and T9 shows second highest 23.53 number of tiller per hill which are statistically similar to each other. Use of combination of vermicompost with inorganic fertilizer reduced the emphasis on chemical fertilizer also with significant increase in the growth and yield characteristic along with quality of rice grain, it is due to different organic sources increase the nutrient status of soil also with increase in cation exchange capacity and increase water holding capacity of soil which increase uptake of nutrients through mass flow. It also supported by Tejada et al., (2009). Bao et al., (2013) also found similar result that combine use of azospirillum biofertilizer in combination of organic and inorganic nitrogen sources in rice showed significant increase in tillers growth and shoot length.

\section{Panicle per hill}

Data recorded from this experiment indicated that treatment number T7 (azotobacter $+25 \%$ vermicompost $+50 \% \mathrm{RDN}$ ) showed $23.55 \%$ higher number of panicle from control treatment (Table 4). Wani et al., (2016) observed the similar findings while conducting study on use of Azotobacter (chroococcum spp.) that Azotobacteria genus synthesizes growth promoters which enhance the agricultural production.

\section{Number of grains per panicles}

Data found from this experiment from each different treatments, the treatment number $\mathrm{T} 7$ (azotobactor $+25 \%$ vermicompost $+50 \%$ $\mathrm{RDN}$ ) and T9 (Azospirillum $+25 \%$ vermicompost $+50 \% \mathrm{RDN})$ showed significantly higher number of grains per panicles (Table 5). Better nourishment gives beneficial effects which increase rate of photosynthesis and assimilation rate. This was also confirmed by findings of Sujatha et al., 2014. 
Table.1 Treatment details

\begin{tabular}{|c|l|}
\hline S. No & Treatment \\
\hline T1 & Control (100\% urea)RDN \\
\hline T2 & $50 \%$ RND + 50\% FYM \\
\hline T3 & $50 \%$ RND + 50\% vermicompost \\
\hline T4 & $50 \%$ RND + 25\%FYM + 25\% cyanobacteria \\
\hline T5 & $50 \%$ RND + 25\%vermicompost +25\% cyanobacteria \\
\hline T6 & $50 \%$ RND + 25\%FYM + 25\% azotobacter \\
\hline T7 & $50 \%$ RND + 25\%vermicompost + 25\%azotobacter \\
\hline T8 & $50 \%$ RND + 25\%FYM + 25\%Azospirillum \\
\hline T9 & $50 \%$ RND + 25\%vermicompost + 25\%Azospirillum \\
\hline
\end{tabular}

Table.2 Effect of different nitrogen sources on the height of direct seeded rice

\begin{tabular}{|l|c|c|c|c|} 
Treatment & $\begin{array}{c}\text { Height- 30 } \\
\text { DAS }\end{array}$ & Height -45 DAS & $\begin{array}{c}\text { Height -60 } \\
\text { DAS }\end{array}$ & $\begin{array}{c}\text { Height- 75 } \\
\text { DAS }\end{array}$ \\
\hline T1 & $33.80^{\mathrm{bc}} \pm 1.30$ & $55^{\mathrm{bcd}} \pm 2.00$ & $88.6^{\mathrm{b}} \pm 1.83$ & $109.88^{\mathrm{b}} \pm 0.41$ \\
\hline T2 & $31.40^{\mathrm{c}} \pm 0.2$ & $52.26^{\mathrm{d}} \pm 1.89$ & $86.20^{\mathrm{b}} \pm 1.00$ & $109.84^{\mathrm{b}} \pm 0.32$ \\
\hline T3 & $32.93^{\mathrm{bc}} \pm 0.9$ & $53.26^{\mathrm{cd}} \pm 1.39$ & $88.26^{\mathrm{b}} \pm 1.26$ & $111.21^{\mathrm{b}} \pm 0.48$ \\
\hline T4 & $35.13^{\mathrm{bc}} \pm 0.6$ & $56.40^{\mathrm{bcd}} \pm 0.50$ & $88.46^{\mathrm{b}} \pm 0.37$ & $111.06^{\mathrm{b}} \pm 0.48$ \\
\hline T5 & $35.06^{\mathrm{b}} \pm 0.54$ & $57.60^{\mathrm{ab}} \pm 0.40$ & $88.8^{\mathrm{b}} \pm 0.11$ & $111.44^{\mathrm{b}} \pm 0.68$ \\
\hline T6 & $35^{\mathrm{b}} \pm 0.83$ & $58.53^{\mathrm{ab}} \pm 0.74$ & $88.53^{\mathrm{b}} \pm 0.26$ & $111.45^{\mathrm{b}} \pm .21$ \\
\hline T7 & $38.46^{\mathrm{a}} \pm 0.93$ & $61.60^{\mathrm{a}} \pm 1.33$ & $92.33^{\mathrm{a}} \pm 1.23$ & $115.23^{\mathrm{a}} \pm 0.37$ \\
\hline T8 & $35.13^{\mathrm{b}} \pm 0.24$ & $57.40^{\mathrm{abc}} \pm 1.38$ & $88.26^{\mathrm{b}} \pm 0.63$ & $111.12^{\mathrm{b}} \pm 0.24$ \\
\hline T9 & $37.80^{\mathrm{a}} \pm 1.11$ & $61.00^{\mathrm{a}} \pm 1.47$ & $91.73^{\mathrm{a}} \pm 0.75$ & $114.03^{\mathrm{a}} \pm 0.32$ \\
\hline
\end{tabular}

The mean followed by different alphabets are significantly different at $\mathrm{P}<0.05$, according to Duncun's multiple range test (DMRT) for separation of means. 
Table.3 Effect of different nitrogen sources on the growth of tillers in direct seeded rice

\begin{tabular}{|c|c|c|c|c|}
\hline Treatment & $\begin{array}{c}\text { Tillers- 30 } \\
\text { DAS }\end{array}$ & $\begin{array}{c}\text { Tillers- 45 } \\
\text { DAS }\end{array}$ & $\begin{array}{c}\text { Tillers- 60 } \\
\text { DAS }\end{array}$ & $\begin{array}{c}\text { Tillers -75 } \\
\text { DAS }\end{array}$ \\
\hline T1 & $4.46^{c d} \pm 0.43$ & $12^{\mathrm{a}} \pm 0.52$ & $15^{\mathrm{b}} \pm 0.23$ & $16.66^{\mathrm{bcd}} \pm .37$ \\
\hline T2 & $3.93^{\mathrm{d}} \pm 0.54$ & $11.60^{\mathrm{a}} \pm 0.83$ & $14.40^{\mathrm{b}} \pm 0.30$ & $15.90^{\mathrm{cd}} \pm .96$ \\
\hline T3 & $4.40^{\mathrm{cd}} \pm 0.40$ & $11.66^{\mathrm{a}} \pm 0.33$ & $14.80^{\mathrm{b}} \pm 0.11$ & $15.43^{\mathrm{d}} \pm 0.29$ \\
\hline T4 & $4.73^{\mathrm{cd}} \pm 0.26$ & $12.26^{\mathrm{a}} \pm 1.42$ & $15^{\mathrm{b}} \pm 0.30$ & $17.06^{\mathrm{bc}} \pm .12$ \\
\hline T5 & $4.80^{\mathrm{cd}} \pm 0.34$ & $12.26^{\mathrm{a}} \pm 1.18$ & $15.26^{\mathrm{b}} \pm 0.48$ & $17.43^{\mathrm{b}} \pm 0.23$ \\
\hline T6 & $5.53^{\mathrm{bc}} \pm 0.26$ & $11.33^{\mathrm{a}} \pm 0.33$ & $15.20^{\mathrm{b}} \pm 0.30$ & $17.73^{\mathrm{b}} \pm 0.17$ \\
\hline T7 & $6.93^{\mathrm{a}} \pm 0.17$ & $13.73^{\mathrm{a}} \pm 0.93$ & $17.8^{\mathrm{a}} \pm 0.74$ & $24.20^{\mathrm{a}} \pm 0.52$ \\
\hline T8 & $4.86^{\mathrm{cd}} \pm 0.48$ & $11.26^{\mathrm{a}} \pm 0.78$ & $15.26^{\mathrm{b}} \pm 0.26$ & $17.26^{\mathrm{bc}} \pm 0.29$ \\
\hline T9 & $6.40^{\mathrm{ab}} \pm 0.23$ & $13.73^{\mathrm{a}} \pm 0.26$ & $17.73^{\mathrm{a}} \pm 0.29$ & $23.53^{\mathrm{a}} \pm 0.52$ \\
\hline
\end{tabular}

The mean followed by different alphabets are significantly different at $\mathrm{P}<0.05$, according to Duncun's multiple range test (DMRT) for separation of means.

Table.4 Effect of different nitrogen sources on panicles in direct seeded rice

\begin{tabular}{|c|c|}
\hline Treatment & Panicle / plant \\
\hline T1 & $17.20^{\mathrm{bc}} \pm 0.1$ \\
\hline T2 & $16.73^{\mathrm{c}} \pm 0.31$ \\
\hline T3 & $16.70^{\mathrm{c}} \pm 0.35$ \\
\hline T5 & $17.46^{\mathrm{b}} \pm 0.27$ \\
\hline T6 & $17.43^{\mathrm{bc}} \pm 0.20$ \\
\hline T7 & $18.46^{\mathrm{b}} \pm 0.29$ \\
\hline T8 & $22.50^{\mathrm{a}} \pm 0.70$ \\
\hline T9 & $18.40^{\mathrm{b}} \pm 0.27$ \\
\hline
\end{tabular}


Table.5 Effect of different nitrogen sources on grain/panicle in direct seeded rice

\begin{tabular}{|c|c|}
\hline Treatment & grain/ panicle \\
\hline T1 & $79.70^{\mathrm{d}} \pm 0.23$ \\
\hline T2 & $76.03^{\mathrm{f}} \pm 0.32$ \\
\hline T3 & $77.75^{\mathrm{e}} \pm 0.52$ \\
\hline T4 & $79.77^{\mathrm{d}} \pm 0.16$ \\
\hline T5 & $81.86^{\mathrm{c}} \pm 0.20$ \\
\hline T6 & $84.34^{\mathrm{b}} \pm 0.24$ \\
\hline T7 & $88.98^{\mathrm{a}} \pm 0.12$ \\
\hline T8 & $82.66^{\mathrm{c}} \pm 1.49$ \\
\hline T9 & $88.62^{\mathrm{a}} \pm .12$ \\
\hline
\end{tabular}

Table.6 Effect of different nitrogen sources on the grain yield in direct seeded rice

\begin{tabular}{|c|c|}
\hline Treatment & Yield per plot \\
\hline T1 & $2.67^{\mathrm{d}} \pm 0.03$ \\
\hline $\mathbf{T} 2$ & $2.32^{\mathrm{e}} \pm 0.031$ \\
\hline $\mathbf{T 3}$ & $2.39^{\mathrm{e}} \pm 0.04$ \\
\hline $\mathbf{T} 4$ & $2.68^{\mathrm{d}} \pm 0.03$ \\
\hline $\mathbf{T} 5$ & $2.93^{\mathrm{c}} \pm 0.08$ \\
\hline $\mathbf{T 6}$ & $3.16^{\mathrm{b}} \pm 0.13$ \\
\hline $\mathbf{T} 7$ & $3.66^{\mathrm{a}} \pm 0.32$ \\
\hline $\mathbf{T} 8$ & $3.23^{\mathrm{b}} \pm 0.03$ \\
\hline $\mathbf{T}$ & $3.62^{\mathrm{a}} \pm 0.04$ \\
\hline
\end{tabular}

The mean followed by different alphabets are significantly different at $\mathrm{P}<0.05$, according to Duncun's multiple range test (DMRT) for separation of means.

\section{Grain yield per plot}

Grain is the economic parameter in cereals crops. Application of different nitrogen sources significantly affects the effects grain yield. Treatments number T7 (azotobacter + $25 \%$ vermicompost $+50 \% \mathrm{RDN})$ and $\mathrm{T} 9$ (Azospirillum $+25 \%$ vermicompost + $50 \% \mathrm{RDN}$ ) showed $27.04 \%$ and $25.95 \%$ higher grain yield with respect to control treatment (Table 6). Pandey and Kumar,
(1989) also reported that with the use of azotobacter bio fertilizer shows significant higher grain yield in comparison to control treatment. Inoculation of bio fertilizer shows much beneficial effect to plant growth and development it is because bio fertilizer makes entophyte bacterial relationships with plant help on plant growth through its life cycle. This is supported by Sturz et al., (2000). Sattar et al., (2014) also reported that inoculation of azospirillum bio fertilizer 
recorded maximum yield $8.43 \mathrm{t} / \mathrm{ha}$ from among the treatments as compared to where the bio fertilizer was not used.

In Conclusion, application of nitrogen form different sources shows significant higher result in growth characteristics and yield characteristic in comparison to the control treatment. Integrated application of different nutrient sources shows sustainability in soil environment which gives synergetic effect on the growth and yield of different crops. Integrated application of nitrogen from different sources makes a balance in environment at micro level with no adverse effect. Use of Integrated nutrient management also helps in manage agriculture residual waste and other wastes by use as nutrient sources combined with synthetics fertilizers. Integrated nutrient management is a beneficial tool for the sustainable agricultural production.

\section{References}

Anonymous (2017). Package of practices of crops of Punjab Kharif 2017. Punjab Agricultural University, Ludhiana.

Anonymous. (2009b). Bio-fertilizer and sustainable forming. In: Bio-Fertilizer for Sustainable Agriculture (Jain, V. K Eds.). pp. 149-179.

Bao, Z., Sasaki, K., Okubo, T., Ikeda, S., Anda, M., Hanzawa, E., Kakizaki, K., Sato, T., Mitsui, M., and Minamisawa, K. (2013). Impact of Azospirillum sp. B510 Inoculation on Rice-Associated Bacterial Communities in a Paddy Field Microbes Environ; 28(4): 487-490.

Das P.K., (1996). In: Organic Farming and Sustainable Agriculture. National Seminar, G.B.P.U.AandT, Pantnagar, pp. 45.

Das, A.C. and Saha, D. (2007). Effect of Diazotrophs on mineralization of organic nitrogen in the rhizosphere soils of rice (Oryza sativa L.). Journal of Crop Weed 3: 69-74.

Densilin D.M., Srinivasan S., Manju P., Sudha S. (2011). Effect of Individual and Combined Application of Biofertilizers, Inorganic Fertilizer and Vermicompost on the Biochemical Constituents of Chilli (Ns - 1701). J Biofertil Biopestici 2:106. doi:10.4172/2155-6202.1000106

Dubey, V., Patel, A. K., Shukla, A., Shukla, S., and Singh, S. (2012). Impact of continuous use of chemical fertilizer. Int J Eng Res Dev, 3, 13-16

Eid, R. A., Abo-Sedera, S. A., and Attia, M. (2006). Influence of Nitrogen Fixing Bacteria Incorporation with Organic and/or Inorganic Nitrogen Fertilizers on Growth, Flower Yield and Chemical Composition of Celosia argenta. World J. Agriculture Sci, 2(4), 450-8.

Tejada, M., and J. L. González (2009). Application of Two Vermicomposts on a Rice Crop: Effects on Soil Biological Properties and Rice Quality and Yield American Society of Agronomy Vol. 101 No. 2, p. 336-344

Maji, N. C. and Mondal, S. R. (2004). Effect of long term use of fertilizers and manures or soil fertility. Environment and Ecology, 22(2): 447-451.

Pandey, A. and Kumar, S.J. 1989. Soil beneficial bacterial and their role in plant growth promotion. Science Indian Research 48: 134-144.

Review. Agricultural Reviews- Agricultural Research Communications Centre India, 23(2), 127-133.

Saajan S., Kamboj, P., Singh, P., Singh, S., Singh, Y., Upadhyay, H., and Kumar, A. (2017). Effect of Different BioFertilizers, Organic and Inorganic Nitrogen Sources on the Yield of Direct Seeded Rice (Oryza sativa) Grown under Punjab 4172 Trends in 
Biosciences 10 (21), Print: ISSN 09748431.

Sattar, A.M., Rahman, F.M., Das, K.D., and Abu T.M.A. Choudhury (2014). Prospect of using azotobactor, azospirillum and cyanobacteria as supplement of urea in rice production in Bangladesh.

Researchgate.net/publication/24218132

0, Volume 336, Issue 1, pp 351-362

Sharma, S. K., Singh, Y. V., Tyagi, S., and Singh, K. K. (2017). Effect of integrated nitrogen management and varieties on seed yield, quality and water saving under aerobic rice (Oryza sativa L.). Journal of Soil and Water Conservation, 16(2), 178-185.

Sireesha, P. V. G., Padmaja, G., Rao, P. C., and Ramana, M. V. (2017). Long-term studies on soil properties and productivity of rice-rice system as influenced by INM in Southern Telangana Zone. Environment and Ecology, 35(3), 1739-1744.

Sturz, A. V., Christie, B. R., and Nowak, J. (2000). Bacterial endophytes: potential role in developing sustainable systems of crop production. Critical reviews in plant sciences, 19(1), 1-30.

Sudhakar, G., Lourduraj, A. C., Rangasamy, A., Subbian, P., and Velayutham, A. (2002). Effect of vermicompost application on the soil properties, nutrient availability, uptake and yield of rice - A

Sujatha, K. Mosha, G. Subbaiah and P. Prasuna Rani (2014). Residual soil fertility and productivity of rice (Oryza sativa L.) As influenced by different organic sources of nitrogen. International journal of plant, animal and environmental sciences; 5 (2): 266289.

Tiwari, A., Tiwari, A., and Singh, N. B. (2017). Impact of Integrated nutrient management on growth characters of rice (Oryza sativa $\mathrm{L}$.).

Wani, S. A. (2012). Effect of balanced NPKS, biofertilizer (Azotobacter) and vermicompost on the Yield and Quality of Brown sarson (Brassica rapa L.) (Doctoral dissertation, M.Sc. thesis, Sher-e-Kashmir University of Agriculture Sciences and Technology, Kashmir, Srinagar).

Wani, S. A., Chand, S., Wani, M. A., Ramzan, M., and Hakeem, K. R. (2016). Azotobacter chroococcum-A potential biofertilizer in agriculture: An Overview. In Soil Science: Agricultural and Environmental Prospectives (pp. 333-348). Springer International Publishing.

Wani, S. P., Shinde, P. A. and Konde (2011). Response of rice (Oryza sativa L.) to Azotobacter inoculation. Current Research, 5 (12). pp. 209-210.

\section{How to cite this article:}

Supreet Saajan, Sumeet Kour, Neetu, Ishita Walia and Arun Kumar. 2018. Effect of Different Combination of Nitrogen Sources on the Yield of Direct Seeded Rice (Oryza sativa). Int.J.Curr.Microbiol.App.Sci. 7(03): 242-249. doi: https://doi.org/10.20546/ijcmas.2018.703.028 